\title{
1990 WORLD MICROCOMPUTER CHESS CHAMPIONSHIP
}

\author{
ICCA Communication \\ by David Levy
}

This event will take place in Lyon, France, from November $24^{\text {th }}$ to December $1^{\text {st }}$. Play will be during the second half of the match for the World Champion title between Kasparov and Karpov.

\section{ENTRY FORM-WORLD MICROCOMPUTER CHESS CHAMPIONSHIP}

\section{LYON, FRANCE}

\author{
November $2^{\text {th }}$-December $1^{\text {st }}, 1990$
}

Authors(s) of the program:

Name and address for correspondence:

Work telephone: Home telephone:

Name of program: Number of games played:

Tournament record: Size of program:

Programming language:

Size of openings book (positions):

Hardware being used in the tournament:

Microprocessor(s) Clockspeed

Which of the authors will come to Lyon?

FOR MANUFACTURERS' GROUP ONLY

The above information must be supplied for all of your machines except a machine in the "unlimited" category.

How many machines are you entering? (delete as applicable) $\quad \begin{array}{llllll}1 & 2 & 3 & 4\end{array}$ Is one of these machines in the unlimited category?

YES NO

Total entry fee: $\$$

Note that manufacturers who enter the unlimited category must pay $\$ 4,000$ U.S. irrespective of whether they enter $0,1,2$ or 3 additional machines. Other manufacturers must pay $\$ 1,000$ per machine. Non-Amateurs in the software group must pay $\$ 1,000$ (only one machine allowed). Amateurs must pay $\$ 250$.

Date of entry: Signature:

At the discretion of the ICCA certain amateur programmers may receive free hotel room and food.

Entries and enquiries should be addressed to:

David Levy

44, Aylestone Avenue,

London NW6 7AA,

England

Telephone: $\quad+44814592388$

Fax: $\quad+44814596422$

Entries should arrive not later than October $24^{\text {th }}$ (Manufacturer's Group) or October $10^{\text {th }}$ (Software Group). 